\title{
State Policy Financial Support of Development of Agricultural Sector
}

\author{
Tatiana Ponedilchuk ${ }^{1, *}$, Igor Paska ${ }^{2}$, Victoria Novikova $^{3}$, Larisa Satyr ${ }^{4}$, and Ruslana \\ Zadorozhna $^{4}$ \\ ${ }^{1}$ Bila Tserkva National Agrarian University, Department of Economics and Economic Theory, pl., \\ 8/1 Soborna, Bila Tserkva, Kyivska oblast, 09117, Ukraine \\ ${ }^{2}$ Bila Tserkva National Agrarian University, Department of Department of Public Administration, \\ pl., 8/1 Soborna, Bila Tserkva, Kyivska oblast, 09117, Ukraine \\ ${ }^{3}$ Bila Tserkva National Agrarian University, Department of Information systems and technologies, \\ pl., 8/1 Soborna, Bila Tserkva, Kyivska oblast, 09117, Ukraine \\ ${ }^{4}$ Bila Tserkva National Agrarian University, Department of Entrepreneurship, Trade And Exchange \\ Activity, pl., 8/1 Soborna, Bila Tserkva, Kyivska oblast, 09117, Ukraine
}

\begin{abstract}
.
Research background: The current state and main directions of state policy of financial security of agriculture production based on the evaluation of financial results of entities that are defined by a set of financial and economic indicators. The problems and prospects of the state policy on directions and volumes of budget support to the agricultural sector by analyzing the content and scope of government support. Despite some positive trends in the development of agriculture of Ukraine, one of its main problems is the lack of funding from the state.

Purpose of the article: The purpose of the study is to identify the according financial policy action for financial providing agricultural production for basic analysis of indicators of its financial and economic development, and identifying key targets for economic growth of the industry.

Methods: The methods of monitoring state regulation of financial support for the development of agricultural sector are: information-analytical, information-statistical, sociological, geo-information.

Findings \& Value added: State financial policy should direct participants in financial relations to implement political, social and economic targets, defining goals and ways to achieve it. The state should play a key role in the innovation process and address its effects on the financial support of research and development and act big, and sometimes the main investor in the new knowledge and technology.
\end{abstract}

Keywords: government funding; government support; financial policy; financial resources, world economic space

JEL Classification: $A 10 ; A 11 ; A 13$

\footnotetext{
* Corresponding author: o.mityay77@gmail.com
} 


\section{Introduction}

In Ukraine, the agricultural sector (agriculture, food and processing industry) has a significant impact on the economy. It generates 17 percent of gross domestic product and about 60 percent of the population consumption fund. In addition, the agricultural sector is one of the main budget-forming sectors of the national economy, whose share in the consolidated budget of Ukraine is 8.9 percent and is the second largest economic sectors in the commodity export structure $[1,2]$.

Despite some positive trends in the development of agriculture of Ukraine, one of its main problems is the continuous decline in public funding. State support for agriculture should be aimed at the overall development of agricultural production based on socioeconomic indicators: salary increase, employment in rural areas and investment attractiveness of the industry on the one hand with another increase revenues to local budgets to create favorable social conditions of rural residents and improve welfare.

\section{Methods}

The methods of monitoring state regulation of financial support for the development of agricultural sector are: information-analytical, information-statistical, sociological, geoinformation.

\section{Results}

The effectiveness of the strategy of the state policy of financial support to the agricultural sector is characterized by a level of financial performance and financial condition of the company, defined by a set of financial and economic indicators (Table 1).

The main directions of the state policy of financial security of agriculture production by the Law of Ukraine "On State Support of Agriculture of Ukraine", the Law of Ukraine "On the State Budget of Ukraine for the current year," the state target program of development of Ukrainian village till 2015", State Target Program sustainable Rural Development for the period until 2020, the concept of comprehensive state reform program and agricultural development of Ukraine program "Agrarian reform in action" and others.

Table 1. General characteristics and results of agricultural enterprises in Ukraine in 2015-2019*

\begin{tabular}{|l|c|c|c|c|c|}
\hline \multicolumn{1}{|c|}{ Indexes } & \multicolumn{5}{|c|}{ Years } \\
\cline { 2 - 6 } & $\mathbf{2 0 1 5}$ & $\mathbf{2 0 1 6}$ & $\mathbf{2 0 1 7}$ & $\mathbf{2 0 1 8}$ & $\mathbf{2 0 1 9}$ \\
\hline Number of companies & 42229,0 & 42595,0 & 42307,0 & 45910,0 & 42949,0 \\
\hline $\begin{array}{l}\text { The average number of workers } \\
\text { employed in agrarian production entities }\end{array}$ & 590198,0 & 582106,0 & 558566,0 & 552192,0 & 503387,0 \\
\hline - per 1 ha & 28,0 & 27,6 & 26,3 & 25,5 & 24,0 \\
\hline Area agrarian lands - total, ha & 21058,7 & 21107,4 & 21232,5 & 21631,9 & 21009,6 \\
\hline -including rented & 19362,7 & 19372,2 & 19509,0 & 19928,0 & 19516,4 \\
\hline $\begin{array}{l}\text { Net income (revenue) from sales } \\
\text { agrarian products and services, mln. }\end{array}$ & 81165,2 & 104082,8 & 132206,1 & 133427,9 & 183529,7 \\
\hline - per 1 ha UAH. & 3854,2 & 4931,1 & 6226,6 & 6168,1 & 8735,5 \\
\hline - Including agrarian products, mln. & 78596,9 & 100681,2 & 128452,6 & 128684,8 & 175828,6 \\
\hline - per 1 ha UAH. & 3732,3 & 4769,9 & 6049,8 & 5948,8 & 8369,0 \\
\hline
\end{tabular}




\begin{tabular}{|c|c|c|c|c|c|}
\hline $\begin{array}{l}\text { Gain on disposal of agrarian products } \\
\text { and services, mln. }\end{array}$ & 14177,6 & 21833,3 & 22683,3 & 14294,1 & 38289,1 \\
\hline - per 1 ha UAH. & 673,2 & 1034,4 & 1068,3 & 660,8 & 1822,5 \\
\hline \begin{tabular}{|l} 
The level of profitability agrarian \\
activity, $\%$
\end{tabular} & 21,2 & 26,5 & 20,7 & 12,0 & 26,4 \\
\hline $\begin{array}{l}\text { Funds received state support - total, mln. } \\
\text { UAH. }\end{array}$ & 4608,1 & 4327,9 & 6974,1 & 7874,0 & 16078,2 \\
\hline - Including from budget subsidies & 1316,0 & 729,3 & 742,0 & 381,9 & 228,7 \\
\hline - The VAT & 3292,1 & 3598,6 & 6232,1 & 7096,1 & 15849,5 \\
\hline - To support crop production & 1790,2 & 2780,5 & 4321,4 & 4519,2 & 13009,7 \\
\hline - For livestock development & 1501,9 & 818,1 & 1910,7 & 2576,9 & 2839,8 \\
\hline $\begin{array}{l}\text { The cost of agricultural production, mln. } \\
\text { UAH., Incl.: }\end{array}$ & 75009,6 & 99265,9 & 123739,3 & 127190,3 & 154313,5 \\
\hline - Labor costs, mln. UAH. & 6806,8 & 9028,9 & 11610,4 & 9719,4 & 11044,1 \\
\hline - In $\%$ of total costs & 9,1 & 9,1 & 9,4 & 7,6 & 7,2 \\
\hline $\begin{array}{l}\text { Deductions for soc. measures } \mathrm{mln} \text {. } \\
\text { UAH. }\end{array}$ & 2434,5 & 3048,9 & 4253,9 & 3565,2 & 4149,4 \\
\hline - In $\%$ of total costs & 3,2 & 3,1 & 3,4 & 2,8 & 2,7 \\
\hline - Depreciation, mln. UAH. & 3963,1 & 4845,7 & 6523,0 & 6971,7 & 8308,7 \\
\hline - In $\%$ of total costs & 5,3 & 4,9 & 5,3 & 5,5 & 5,4 \\
\hline - Rent for land shares, mln. UAH. & 5259,5 & 6367,4 & 9758,5 & 11292,7 & 12784,5 \\
\hline - In $\%$ of total costs & 7,0 & 6,4 & 7,9 & 8,9 & 8,3 \\
\hline - Rent for property shares, mln. UAH. & 75,8 & 68,4 & 59,6 & 68,4 & 103,4 \\
\hline - In $\%$ of total costs & 0,1 & 0,1 & 0,0 & 0,1 & 0,1 \\
\hline The rent for 1 ha UAH. & 253,4 & 304,9 & 462,4 & 525,2 & 613,4 \\
\hline Wages per 1 hectare, USD. & 323,2 & 427,8 & 546,8 & 449,3 & 525,7 \\
\hline Social contributions 1 hectare, USD. & 115,6 & 144,4 & 200,3 & 164,8 & 197,5 \\
\hline Depreciation on 1 hectare, USD. & 188,2 & 229,6 & 307,2 & 322,3 & 395,5 \\
\hline State support for 1 ha UAH. & 218,8 & 205,0 & 328,5 & 364,0 & 765,3 \\
\hline - The VAT, UAH. & 156,3 & 170,5 & 293,5 & 328,0 & 754,4 \\
\hline
\end{tabular}

* Table is calculated based on the statistical bulletin "Basic economic indicators of agricultural production in the agricultural enterprises for 2015-2019 year" [3,4]

Let us analyse the composition of government expenditure aimed at funding the development of agriculture of Ukraine during recent years (Table 2).

The total amount of expenditure over the period decreased by 352.8 million. UAH (or $6.13 \%$ ). Regarding the structure of expenditures, the largest share in the total in 2018 with spending on training, retraining and workforce $-54.2 \%$, the share of this area has increased by $14.66 \%$, while - at $45.44 \%$. For this area provides for funding training for agriculture universities I-II and III-IV accreditation level, institutions of postgraduate education and training of workers [9].

Another important component is government support for the livestock industry $13,83 \%$ of the total expenditure in 2018. It should be noted that funding for the development of livestock in 2016 had the largest share in the structure of spending on 
agriculture $-37.8 \%$. Now there is a significant cost reduction in this area - at $36.27 \%(75.12$ million UAH) compared to 2014, which may adversely affect the livestock industry.

Table 2. Dynamics of financing costs Ministry of Agriculture through the General Fund of the State Budget of Ukraine

in 2016-2018, thousand. UAH [5,6]

\begin{tabular}{|c|c|c|c|c|}
\hline Codes & $\begin{array}{c}\text { Expenditures by } \\
\text { program classification }\end{array}$ & 2016 & 2017 & 2018 \\
\hline 2800000 & Total & 5571686,4 & 5865009,1 & 5218908,0 \\
\hline & in support of agricultural enterprises, total & 1792763,4 & 1128932,9 & 187992,0 \\
\hline & of them major support programs & 1677616,5 & 966083,1 & 717779 \\
\hline 2801000 & $\begin{array}{l}\text { Apparatus Ministry of Agriculture, } \\
\text { including }\end{array}$ & 3477355,3 & 3157666,4 & 2314230,0 \\
\hline 2801010 & $\begin{array}{l}\text { General management and management of } \\
\text { APC }\end{array}$ & 35069,8 & 38535,6 & 39757,8 \\
\hline 2801050 & $\begin{array}{l}\text { The research and applied scientific } \\
\text { research and development, works for the } \\
\text { state target programs and public order in } \\
\text { the field of agriculture, training of } \\
\text { scientific personnel }\end{array}$ & 13011,7 & 136512,3 & 107122,8 \\
\hline 2801080 & $\begin{array}{l}\text { Training for agriculture universities I-II } \\
\text { levels of accreditation, } \\
\text { methodological support of educational } \\
\text { institutions }\end{array}$ & 698943,0 & 811992,8 & 843101,8 \\
\hline 2801100 & $\begin{array}{l}\text { Training for agriculture universities III-IV } \\
\text { level of accreditation, } \\
\text { methodological support of educational } \\
\text { institutions }\end{array}$ & 709840,7 & 1083200,8 & 779378,2 \\
\hline 2801180 & $\begin{array}{l}\text { Financial support measures in agriculture, } \\
\text { including }\end{array}$ & 327274,2 & 822376,6 & 71777,9 \\
\hline 2801200 & $\begin{array}{l}\text { Measures to combat pests and diseases SG } \\
\text { plants, preventing the spread of } \\
\text { infectious animal diseases }\end{array}$ & 902,5 & 34000,0 & 25500 \\
\hline 2801310 & $\begin{array}{l}\text { Organization regulation of institutions in } \\
\text { the system of agriculture and } \\
\text { support of the Agrarian Fund }\end{array}$ & 10821,2 & 25972,0 & 24339,1 \\
\hline 2801470 & $\begin{array}{l}\text { Financial support Ukrainian Laboratory of } \\
\text { Quality Safety of Agricultural } \\
\text { Products }\end{array}$ & - & 10000,0 & 6054,5 \\
\hline 2802000 & $\begin{array}{l}\text { The State Veterinary and Phytosanitary } \\
\text { Service of Ukraine, including }\end{array}$ & $\mathbf{9 7 3 2 2 3 , 8}$ & 1255349,4 & 1302236,5 \\
\hline 2802015 & $\begin{array}{l}\text { Leadership and Management in Veterinary } \\
\text { Medicine and Phytosanitary } \\
\text { Service of Ukraine }\end{array}$ & 123738,0 & 287586,4 & 297058,5 \\
\hline 2802020 & $\begin{array}{l}\text { Disease control measures and participation } \\
\text { in OIE }\end{array}$ & 102679,3 & 108769,8 & 103214,1 \\
\hline 2802030 & $\begin{array}{l}\text { Organization regulation of institutions in } \\
\text { the system of the State Veterinary } \\
\text { and Phytosanitary Service }\end{array}$ & 645624,1 & 858845,64 & 901813,9 \\
\hline 2803000 & $\begin{array}{l}\text { The State Agency of Land Resources of } \\
\text { Ukraine, including }\end{array}$ & 383639,3 & 898706,4 & 1105195,6 \\
\hline
\end{tabular}




\begin{tabular}{|c|c|c|c|c|}
\hline 2803010 & $\begin{array}{l}\text { Leadership and management in the field of } \\
\text { land resources }\end{array}$ & 368220,4 & 780242,9 & 606994,8 \\
\hline 2803030 & Land reform & 12015,7 & 95932,0 & 476577,1 \\
\hline 2804000 & $\begin{array}{l}\text { The State Agency of Ukraine fisheries, } \\
\text { including }\end{array}$ & 189077,2 & 252831,1 & 213131,1 \\
\hline 2804010 & Leadership and Management in Fisheries & 7149,4 & 91644,4 & 104980,6 \\
\hline 2804020 & $\begin{array}{l}\text { The organization and activities of fisheries } \\
\text { and fish reproduction complexes }\end{array}$ & 118375,4 & 58197,7 & 44972,1 \\
\hline 2804030 & $\begin{array}{l}\text { Applied scientific and technical } \\
\text { developments, works for the state target } \\
\text { programs and state order in fisheries }\end{array}$ & 3542,0 & 3556,2 & 2372,5 \\
\hline 2804070 & $\begin{array}{l}\text { Selection fisheries and reproduction of } \\
\text { aquatic biological resources in inland } \\
\text { waters and the Black Sea }\end{array}$ & 6600,0 & 54080,0 & 8800,0 \\
\hline 2807000 & $\begin{array}{l}\text { State Agricultural Inspection of Ukraine, } \\
\text { including }\end{array}$ & 221116,6 & 300455,8 & 185244,6 \\
\hline 2807010 & $\begin{array}{l}\text { Implementation of state control in the field } \\
\text { of agriculture of Ukraine }\end{array}$ & 4730,2 & 293148,0 & 180245,8 \\
\hline
\end{tabular}

The current practice of direct public funding of agriculture of Ukraine did not ensure effective and efficient use of financial resources. Using these funds were in violation of certain requirements of the current legislation, no clear criteria for determining the allocation of funds, and most were not worked out a clear strategy for development of the agricultural sector [7-9].

Unfortunately, Ukraine is rapidly losing market of genetic resources (seeds-varietal crop and livestock breeds). By purely Ukrainian cultures such as corn, sunflower, sugar beet, potatoes, vegetables, and melons in Ukraine has already registered more than $50 \%$ of foreign species selection [10].

Cancelled funding a number of important programs to support the agricultural sector, including: scientific developments in standardization and certification of agricultural products, state support of agricultural service cooperatives, funding for protection, reproduction and improvement of soil fertility, budgetary livestock subsidies and state support of crop production State support for agricultural advisory services program of partial compensation of sophisticated agricultural machinery of domestic production and procurement of breeding heifers and cows, domestic equipment for agriculture, followed by the implementation of an agricultural enterprise under financial leasing. (tab.3) [11,12]

Not Effective proved and the State Program of development of domestic machinery for agriculture, which led to the fact that the domestic market for almost $80 \%$ of sales accounted for by technical means foreign production, while the existing machine-tractor fleet by nearly $70 \%$ needs to be changed [13].

Table 3. Dynamics of financing costs Ministry of Agriculture through a special fund of the State Budget of Ukraine

in 2016-2018, thousand UAH [11,12]

\begin{tabular}{|c|c|c|c|c|}
\hline Codes & Expenditures by program classification & 2016 & 2017 & 2018 \\
\hline 2801180 & Financial support measures in agriculture & 0,0 & 1577,6 & 5000,0 \\
\hline
\end{tabular}




\begin{tabular}{|c|c|c|c|c|}
\hline 2801250 & $\begin{array}{l}\text { Agrarian Fund expenses associated with a } \\
\text { set of measures for the storage, } \\
\text { transportation, processing and } \\
\text { export of objects of state price regulation } \\
\text { of state intervention fund }\end{array}$ & 413454,9 & 284820,3 & 500000,0 \\
\hline 2801350 & $\begin{array}{l}\text { State support of hop, laying young } \\
\text { orchards, vineyards } \\
\text { and berries and supervision of }\end{array}$ & 655000 & 746777,5 & 100000,0 \\
\hline 2801460 & Providing loans to farmers & 28000,0 & 27800,0 & 27900,0 \\
\hline 2801490 & $\begin{array}{l}\text { Financial support measures in agriculture } \\
\text { on financial } \\
\text { leasing }\end{array}$ & 85000,0 & 25000,0 & 8842,5 \\
\hline 2801540 & State support for the livestock industry & 621288,9 & 564568,7 & 650000,0 \\
\hline 2801560 & $\begin{array}{l}\text { The formation of public intervention fund } \\
\text { Agrarian Fund, as well as procurement of } \\
\text { material and technical } \\
\text { resources for SH Manufacturers }\end{array}$ & 5888098,4 & 5974559,9 & 7200000,0 \\
\hline 2803600 & $\begin{array}{l}\text { Titling the right to private ownership of } \\
\text { land in rural } \\
\text { areas }\end{array}$ & 0,0 & 0,0 & 106005,6 \\
\hline & TOTAL & 7609730,6 & 7601514,1 & 8597748,1 \\
\hline & $\begin{array}{l}\text { including in support of agricultural } \\
\text { enterprises }\end{array}$ & 7194039,3 & 7315283,8 & 7991742,5 \\
\hline
\end{tabular}

In 2015 the program was cancelled public funding laying on young orchards, vineyards and berries and supervising them.

\section{Conclusion}

The most effective today is a form of indirect state support of agricultural producers on the basis of a special VAT regime, which allows you to leave it at the disposal on productive activities. Experts estimate the total amount of the state support in 2019 exceeded 16 bln. UAH, which on average is 754 USD. 1 ha. However, with the decrease in the tax burden in agriculture, investment (public benefits) is not accompanied by the modernization of existing facilities and increased focus on exports [14-17].

The most influential negative factor in the current situation is the lack of state policy of agriculture and support domestic producers, without providing interaction of all participants in the state, scientific and industrial sectors of agriculture, which led to the adoption of inefficient management decisions and ineffectiveness of such support and not promoted as effective development of the industry, and solving social problems of rural areas.

State support of the village in Ukraine due not only common features of agricultural production, and the fact that the conducted reformation, change of ownership, the creation of new legal forms of enterprises transition to market principles of management, etc., caused a number of social and demographic reforms in agriculture that began after Ukraine gained independence implemented inconsistently, did not have the character of consistency and comprehensiveness [18-22].

State financial policy should direct participants in financial relations to implement political, social and economic targets, defining goals and ways to achieve it. The state should play a key role in the innovation process and address its effects on the financial support of research and development and act big, and sometimes the main investor in the new knowledge and technology. 


\section{References}

1. L.L. Lazebnyk - K. (2014) Finansovi integration mechanisms and modernization of the national economy L. Institute of agrarian economics journal, 444- $480 \mathrm{p}$.

2. Ed. M.Y., Demyanenko (2016). The state policy of financial support to the agricultural sector AIC: Monograph. Institute of agrarian economics journal , 342- $372 \mathrm{p}$.

3. Haidai O., Chukina I., Svitovyy O., Vasylenko O., Diachenko M. and Udovenko I. (2019). Socio - Economic Direction of Agricultural Sector Development in Ukraine. Proceedings of the 33rd International Business Information Management Association Conference (IBIMA)., 10-11 April, Granada, Spain, P. 7011-7018.

4. Melnyk, L., Derykolenko, O., Kubatko, O., \& Matsenko, O. (2019). Business models of reproduction cycles for digital economy. Proceedings of the 15th International Conference on ICT in Education, Research and Industrial Applications. Integration, Haronization and Knowledge Transfer. Volume II: Workshops. Kherson, Ukraine, June 12-15, (pp. 269-276).

5. Haidai, O., Chukina, I., Movchanyuk, A., Kovalenko-Chukina, I., Mashkovska, L., \& Ponedilchuk, T. (2019). Factors of decreasing risks of manufacturing and economic activity of agricultural enterprises as the basis of their competitiveness. In Proceedings of the 33rd International Business Information Management Association Conference, IBIMA 2019: Education Excellence and Innovation Management through Vision 2020, 7062-7070.

6. Reznik, N. P., Srivastava, V., Nekryach, A., Martynenko, S., Naumenko, R., Haidai, O., \& Petrenko, N. (2019). Decentralization of authorities in Ukraine; as an efficient instrument for strengthening local democracy in the modern stage of government. International Journal of Engineering and Advanced Technology, 9(1), 6786-6792.

7. Haidai, O., Bahorka, M., Satyr, L., Bondarchuk, N., \& Yurchenko, N. (2020). Complex procedure for implementation of the strategy of competitiveness ensuring of Ukraine's agrarian sector. Management Theory and Studies for Rural Business and Infrastructure Development, 41(4), 537-546.

8. The state policy of financial support to the agricultural sector AIC: Monograph / [M.Y. Demyanenko, Sabluk PT, V.M. Skupy'j etc.] ; Ed. M.Y., Demyanenko. - K .: NSC "IAE", 2011. - 372.

9. The official site of the State Statistics Service of Ukraine [electronic resource]. Retrieved from: http://www.ukrstat.gov.ua/.

10. The Law of Ukraine № 1877-15 «On state support of agriculture of Ukraine" [electronic resource]. Retrieved from : http://zakon3.rada.gov.ua/laws/show/1877-

11. Mityay, O., Gryshova, I., \& Kryukova, I. (2015). Ukraine's positions in international ratings evaluation as a factor of its competitiveness. Ekonomicnij Casopis-XXI (Economic Annals-XXI), (5-6), 24-27.

12. Gryshova, I. Y., Mityay, O. V., \& Kuzhel, V. V. (2016). Competitive position stability of agricultural sector of Ukraine at internal and external markets. Актуальні проблеми економіки, 177(3), 66-72.

13. Mityay, O. V. (2016). Assessment of competitive capacity of agrarian sector branches. Актуальні проблеми економіки, 178(4), 213-220.

14. Gryshova, I. U., \& Mityay, O. V. (2016). The estimation of the enterprise trade name competitiveness. Науковий вісник Полісся, 6(2), 85-91.

15. Naymova, L. N., Mityay, O. V., \& Galitsky, A. N. (2016). Development of the innovative enterprises of the agrarian production in the current economic system of Ukraine. Науковий вісник Полісся, 7(3), 124-129. 
16. Coviello, D., \& Gagliarducci, S. (2017). Tenure in Office and public procurement. American Economic Journal: Economic Policy, 9(3), 59-105.

17. Palguta, J., \& Pertold, F. (2017). Manipulation of procurement contracts: Evidence from the introduction of discretionary thresholds. American Economic Journal: Economic Policy, 9(2), 293-315.

18. Mironov, M., \& Zhuravskaya, E. (2016). Corruption in procurement and the political cycle in tunneling: Evidence from financial transactions data. American Economic Journal: Economic Policy, 8(2), 287-321.

19. Meng, Z., Wu, Z., Muvianto, C., \& Gray, J. (2017). A Data-Oriented M2M Messaging Mechanism for Industrial IoT Applications. IEEE Internet of Things Journal, 4(1), 236-246.

20. Mihardjo, L. W. W., Sasmoko, Alamsyah, F., \& Elidjen (2019). Boosting the Firm Transformation in Industry 5.0: Experience-Agility Innovation Model. International Journal of Recent Technology and Engineering, 2S9(8), 737-742.

21. Xiaofeng Xu, Zhifei Wei, Qiang Ji, Chenglong Wang, \& Guowei Gao (2019). Global renewable energy development: Influencing factors, trend predictions and countermeasures. Resources Policy, 63, 101470.

22. Zhang, Y. (2019). Research on key technologies of remote design of mechanical products based on artificial intelligence. Journal of Visual Communication and Image Representation, 60, 250-257. 